\title{
Is High School Grade Point Average A Sufficient Measure For Admission To College English Departments?
}

Khalid Mohammed Alwahibee, Ph.D., Imam Mohammed Bin Saud Islamic University, Saudi Arabia

\begin{abstract}
This paper tried to investigate the differences between two groups of students who have been admitted to the English departments based on two different methods of admission. The first group (A) was admitted directly to the department based on their high school GPA, while the other group (B) was admitted based on the level of their replacement test which placed them into the intensive English program. The results of the study showed that more (22.2\%) of the students, who directly admitted to the department, were at risk of failure. On the other hand, students who have studied in the intensive English program before being admitted to the English department, showed better result since (4\%) of the students were at risk of failure. The answers of the rest of questions on this paper were in favor of group (B). Finally this paper presented some valuable suggestion which are useful for English department administrator.
\end{abstract}

Keywords: High School GPA Vs. Placement Tests; Saudi Arabia

\section{INTRODUCTION}

(C) ome Saudi Universities have discontinued the use of admission tests for admission to Departments of English. Other universities, after nearly two years of not testing, have resumed their use. The universities that have cancelled the tests claim that high school grade point average (GPA) is sufficient enough for admission. On the other hand, those universities that resumed the tests claim that they have admitted low English level students, which has caused problems for the students as will as the departments. As a result of the direct admission depending on high school GPA, Al-Jarf (2008) has found that only $21.8 \%$ of the female students passed the reading course, the attrition rate increases one year after another. Newer universities, such as Al-kharj University, have two Departments of English. One Department offers a B.A while the other, in the community college, offers a Diploma. One Department admits students based on the GPA of high school and does not require admission test while the other requires the test. In this study, two groups from these two different departments will be compared according to their high school GPA, placement tests, and the GPA after the first semester in the department. It is expected that in this experimental study will either support or reject Al-jarf's study.

\section{Statement of the Problem:}

As a teacher of English and as a dean of the community college, I have always insisted that students applying to the Department of English, who are graduating from Saudi high schools and have never been abroad, should be evaluated before being admitted. Some teachers, in the Departments of English in other colleges complained about the weak and the low level of the English language of their students. Most of the students, if not all, have been directly admitted to the department, based on their GPA. Therefore, this claim of the students' weakness in the English language, which threats their future in Department of English, is a problem by itself. 


\section{Purpose of the Study}

This study will compare between two different policies of admission to the Departments of English. One department requires a placement test while the other admits students directly to the department based on the GPA of their high school. It will check the effect of both policies on students' later achievement.

\section{Significance of the Study}

This study should show the importance of the placement test or may reject it. If it supports it, then the results should be generalized to all Departments of English in the Kingdom of Saudi Arabia. Otherwise, all departments should depend on the GPA.

\section{Research Questions:}

- Will students who are admitted to the English Department based on their GPA show better results at the end of first semester?

- Will students who are admitted to the English Department based on the replacement test show better results at the end of first semester in the English department?

- Will students who are admitted to the English Department based on their GPA show better results in the placement test?

- Is there a significant difference between the results of the two groups in the replacement test after one semester of study?

- Is there a significant difference between the mean scores for the two groups GPA after one semester of study?

- What are the other possible means to check student's English level before admission?

\section{LITERATURE REVIEW}

\section{Definitions of Terms}

GPA: grade point average. Here it refers to Saudi high school average grade after graduation. This grade includes the average marks of all subjects, which a student studies during the last two years of his or her high school, which includes English class.

Admission test: It is a test that is set by the Department of English in which students are required to get a definite grade decided by the test's designer in order for a student to be admitted to the Department of English.

A placement test: It is the same as the admission test, however, those students who do not achieve the required score for direct admission to the English program, they are replaced in either an A- level intensive English course in which they study for one semester or a B- level intensive course in which a student study for two semesters. Those who earn below a designated score, which is decided by the department will be directed to other departments.

\section{Previous Studies}

Unfortunately, little literature can be found in regard to using high-school GPA as a sufficient measure and a success indicator for students enrolled into the Departments of English. Most of the studies concentrate on comparing high school GPA with ACT (American college test) as predictors for academic success in college. Noble, J. \& Sawyer, Richard L. (2004) compared the effectiveness of high school GPA and ACT. They found that students' scores in both predicated they would achieve moderate levels of first - year GPA and that High school GPA is somewhat more accurate. However, in higher college levels, GPA was not a good predictor. On the other hand, they found that ACT predicted that student would succeed at all other levels. 
Selim and Alzarooni (2009) tried to predict the performance of students who have been admitted to the engineering program based on their high school GPA. In their introduction they quoted (Austin, 1993) and stated that "high school grades provide college admission officers one good indication of students academic ability" (p. 145). Moreover, they added that GPA "is not necessarily a good means of comparing students' experience and achievement. This is because high school grades reflect standards and quality of a particular school or school system" (p.145). As is the case in Saudi Arabia, schools differ from one to another in setting these standards. Therefore, student high school GPAs differ on the basis of region, district, individual school (government or private). Thus, many students get high GPA and therefore, they are admitted to the department they wish, regardless their ability in going well in these departments.

To solve such problems, many universities and universities admission officers, created some standardized examinations to provide an assessment to measure the potentiality of the students. As for English language applicants must meet the English-language requirements for college admission. Al-Jarf (2008) summarized them in the following:

- $\quad$ At least two years of foreign language classes in high school.

- Proof of English language proficiency in any of the following ways: Six credits of post-secondary English, English 12 and two years of high school in Canada, Advanced Placement English Language/Composition or English Literature/ Composition, International Baccalaureate English Language, Language Proficiency Index Level 4, four years of full time study in English in Canada at a high school or post secondary institution.

- A satisfactory standard in a university-approved English test such as IELTS (International English Language Testing Service), TOEFL (Test of English as a Foreign Language), University of Cambridge Local Examination Syndicate, CAE (Certificate in Advanced English), ESOL (Pitman English for Speakers of Other Languages), GCSE or O-Level, Edexcel (London Test of English), UCLES International (GCSE English as a Second Language), ELA (English Language Assessment Test), CAEL (Canadian Academic English Language Assessment Test).

- $\quad$ Competency-based admissions policies and procedures. These are used by some of the USA universities.

- 5-Competency-based admissions policies and procedures. (p. 60-61)

In regard to studies showing the importance of placement tests in Saudi college context, there was only one study to the best of knowledge of the author of this research. Al-Jarf (2008) tried to investigate the effect of canceling the admission policy, which that a placement test for female applicants with high school GPA. She found that:

Despite the fact that the lowest GPA for high school graduates admitted to the College of Languages \& Translation (COLT) in Fall 2007 was 98.3\%, results of the fall 2007 final exams were exceptionally shocking with only 21.8\% passing the reading course. The attrition rate in Fall 2003 was $20 \%$ and it went up to 30\% in Spring 2004. Few students drop each week and many re-register in the following semester adding up to the total number of enrollees. This status quo shows a need for adopting new admission benchmarks at Saudi language and translation schools. Recommendations for improving the current status are given. (Al-Jarf, 2008, p.60)

\section{METHODOLOGY AND PROCEDURES}

\section{Subjects}

Two groups of English freshmen students were tested. The first group is consisted of 25 students participating in the exam out of 59 students enrolled in the Department of English at the college of science and humanity studies (henceforth group A). This group has been admitted directly to the program based on their GPA. The second group is consisted of 21 students who have passed the admission test out of more than 125 applicants who were studying in the Department of English at the community college (2 years Diploma Degree) (henceforth group B). This group was admitted to the intensive English program for their first semester after taking a placement test. 


\section{Instruments}

A placement test consisting of 100 questions was prepared by the Department of English at the community college. It is consisted of three parts. The first part was assigned for an unseen listening exam. The second part was reading comprehension with several questions concentrating on direct, indirect and referential questions. The third part included grammar, vocabulary, sentence structure and dictation. All 100 questions have been collected and prepared from the English books of the primary and high schools of the ministry of education.

\section{Data Collection and Procedures}

Data was collected on many stages. The first stage was during the first month at the beginning of the second semester of the academic year 2009/2010 (the first semester for the students' enrolment for group A). Two English language instructors administered the Exam. Audio cassette were played for the listening part. Then students were asked to start answering the exam. They were told to take it seriously since it will show them how much they will do in future. On the other hand, Group B's exam was collected from the department archive because it was only 5 weeks old since it was used to place new students into the English program. The students participated in group B were the only students passed the admission test. Both groups' placement tests and high school GPA were listed in tables (see appendixes: 1,2,3, and 4).

\section{DATA ANALYSIS}

Results of the placement exams (tests) for both groups were analyzed and compared. Also, High school GPA and English subject grades for the final year at the high school for students of group A were also shown and discussed. Moreover, all three involved results: High school GPA, English Subject results, and placement results were compared. Percentage, average and frequencies of students' GPAs after the first semester of study were computed and calculated.

\section{RESULTS}

As shown in table 1, we can notice that all students in Group A, who were admitted to the Department of English at the college of science and humanity studies, who also showed high score in the English subject, got low grades in the placement test, with an average grade (39.4). Also, students GPAs after one semester among the participated students in group A was 3.56 while it was 3.52 for group B. though it showed no big difference between directly admitted students and students who have been admitted according to their grades in the placement test, yet this can be justified as follows:

- $\quad$ Group A students were expected to do better according to their outcome during high school.

- $\quad$ Only 25 out of 59 students participated in the placement test and those students were classified to be among the best students in the class who really care about their study in the department.

- $\quad$ This difference in the GPA after the first semester will be changed if the GPA for the total number of students is added up. After adding it all up, it will become to be 3.06 (see table 3).

On the other hand, table \# 1 shows that Group B got good results in the placement test with an average of $(72.16 \%)$. When we compare this grade to the grade that was achieved by the students whom they had been admitted directly that showed (39.4); we notice a big difference in favor of students who were admitted on the basis of their placement test, this can also be justified as follows:

- Students who have been admitted on the basis of their placement test had to compete with other applicants to the department; therefore, they tried to do their best in order to be admitted.

- $\quad$ Those students admitted were good in English in the first hand.

- $\quad$ The exam was part of what they have studied during their high school; therefore, it was easy to earn good grades. 
The above results clearly shows that, despite the high GPA for high school students applying to the English programs and their high marks in the English subject, they showed very low proficiency level in the English language. On the other hand, those who have been given an admission test, only those who showed good grades were admitted to the second program. As a result for both policies we can deduce the following:

- Many students in group A dropped the course (4 students), while in group B none of the students have dropped out the course (see tables 2 and 3)

- $\quad$ Eight students in group A got an (F) grade, while none of the students in group B got (F).

- $\quad$ Four students in group A got a (D) grade, while only one student earned a (D) in group B.

- $\quad$ Seven students in group A got $(\mathrm{D}+)$, while eight students got $(\mathrm{D}+)$ in group $\mathrm{B}$.

- $\quad$ The Above grades F, D \& are considered as at risk students since any failure in any of the subjects in the following semester of study, will cause them to have low level grades and then may get a warning letter if their GPA goes below 2.0. From the above we infer that group A students $22.2 \%$ are at risk, while at risk students from group B is $4.7 \%$.

- The next group of students that can be classified as near at risk are those who fall in the grades 2.5 to 3.0 GPA. Seven students in group A with grades fall between 2.6 and 2.84. On the other hand eight students fall between 2.6 to 2.96 .

- Comparing the grades of students in the English subject to the grades of the placement test, we can notice a big difference except for some students (see table \# 6). The low grades in the placement test reflect their real knowledge level of English.

The results of this study are consistent with the findings of Al-Jarf (2008), which found that many female Saudi high school graduates are not well prepared to be enrolled in a department of English language. This of course is clear from the above findings, which showed low grades in the placement tests in addition to the number of atrisk students. As it was mentioned in the review of literature of Al-Jarf: enrolment to the colleges of languages and translation based on high school GPA, caused many attritions, and failing in some subjects. This study also showed that some students have drawn out from the English program. Moreover, others were at -risk to go below 2.0 GPA.

The findings of this study, also is consistent with Olsen (2006) which tried to investigate the importance of placement test to provide high school who are planning to enroll to California State University (CSU) with an early signal of whether they have the English and math skills necessary for college, and to offer help for those who do not. They found that the placement tests identified 47 percent of incoming freshmen in 2004 as needing remedial instruction in English, and 37 percent as needing it in math.

There are other studies that are consistent with the finding of this study. As shown in the results of the placement test of group A, students who got very low grades which gives an indication of the future of the students. Costrell (1993) found that a lower admission standard reduces performance. This is typically what happened to some of the students in group A who drawn out from the program or had low GPA at the end of first semester of enrollment.

Also, the instructors and heads of the departments in Al-Jarf study, recommended that an admission test be given to all high school graduates wishing to join COLT. This study also asserts the importance of Admission test or at least a placement test for those students who wish to join the Departments of English. Al-Jarf (2008) also indicated that those universities that had similar problems with students' admission reviewed their policies and established new admission benchmarks that were proved to be effective. For example, the Department of English at the college of languages and translation at Imam Mohammed Ibn Saud Islamic University resumed their old policy of giving an admission test that is also used for a placement test for students wishing to be enrolled into their department. This decision had come after many complaints from the teachers at the first and second semester who complained about the weakness of those students.

The admission test which is used at the same time as a placement test which is administered to group $\mathrm{B}$, is supported by the findings of Al-jarf (2008) who indicated that the subjects of her study suggested that students admitted to COLT must score $60 \%$ and above on the English Language Proficiency Test, on the Arabic Language proficiency Test, on the translation, on the Computer Literacy and on the General Knowledge Tests. Though, the test 
administered to the students of this study consisted of different parts, yet we can say it was more comprehensive and more authentic to what students have studied during high school.

Answering the research questions:

1- Will students who are admitted to the Department of English based on their GPA show better results at the end of first semester?

To answer this question, we can say NO, since more than $22.2 \%$ of the students are at risk.

2- Will students who are admitted to the Department of English based on the replacement test show better results at the end of first semester in the Department of English?

To answer this question, we can say YES, since only $4.7 \%$ of the students are at risk.

3- Will students who are admitted to the Department of English based on their GPA show better results in the placement test?

To answer this question, we can say NO since the average grade of the total number of student who took the test was 39.4 , which is considered very low.

4- Is there a significant difference between the results of the two groups in the replacement test after one semester of study?

To answer this question, we can say YES, of course there is a significant difference which lies in the frequencies of the number of students earning $\mathrm{F}, \mathrm{D}$, and $\mathrm{D}+$ which was in favor of group $\mathrm{B}$.

5- Is there a significant difference between the main scores for the GPA of the two groups after one semester of study?

To answer this question, we can say YES. Group A's GPA was 3.06 while group B's GPA was 3.52

6- What are the other possible means to check student's English level before admission?

To answer this question, we can say there are many possible ways, some of which have been mentioned by this study. Other means, like TOEFL exam.

\section{CONCLUSION}

As for the findings of this study and other studies mentioned, university officers, department heads, and deans of colleges should pay attention to the following suggestions:

- $\quad$ Screening students before admission to the university in general is very important.

- $\quad$ This screening may save the university money, students and teachers' time and effort.

- Some departments, such as English language programs, must do screening exams such as placement tests, or admission tests to admit only students who are believed to continue studying in the department until they graduate with a good GPA at least.

- $\quad$ Placement and admission tests must be prepared and composed of the books of English at the high school to reflect true knowledge of the students.

- University admission officers, and language deans should work with the ministry of education to inform the students of the importance of these exams and this also should be publicized in order for students to prepare themselves.

\section{AUTHOR INFORMATION}

Dr. Khalid Alwahibee is a Professor of English language at Imam Mohammed Bin Saud Islamic University, Riyadh, Saudi Arabia. He is also a Saudi cultural attaché in Egypt since 2011-2015. Email: nour rahim@yahoo.com or alwahibee@hotmail.com 


\section{REFERENCES}

Al-jarf, R. (2008) " A call for New Benchmarks at Saudi Language and Translation schools". Asian-efljournal.com. V. 10. Issue 4, Dec 2008.

Noble, J. \& Sawyer, R. (2002). Predicting different levels of academic success in college using high school GPA and ACT Composite score. ACT Research Report 2002-4. Iowa City, IA: ACT.

Selim, M. \& Alzarooni, S. (2009). "Do Secondary School Grades Predict the Performance of Engineering Students?". Australasian Journal of Engineering Education, V. 15 Issue 3, 2009.

Olson, L. (2006). California high schoolers get preview of college-placement test. Education Week, $25,33,27$.

Costrell, Robert M. (1993). An economic analysis of college admission standards. Education Economics, 1(3), 227241. 


\section{APPENDIX 1}

Table 1. placement test results for both groups

\begin{tabular}{|c|c|c|}
\hline Student \# & Group A Test R. & Group B Test R. \\
\hline $1-$ & 24 & 70.6 \\
\hline $2-$ & 62 & 82.4 \\
\hline $3-$ & 28 & 73.8 \\
\hline $4-$ & 36 & 95 \\
\hline $5-$ & 25 & 88 \\
\hline $6-$ & 52 & 82.6 \\
\hline $7-$ & 33 & 64.8 \\
\hline $8-$ & 28 & 82.8 \\
\hline 9- & 33 & 76.4 \\
\hline $10-$ & 23 & 93.6 \\
\hline $11-$ & 67 & 80.8 \\
\hline $12-$ & 36 & 73.6 \\
\hline $13-$ & 45 & 62 \\
\hline $14-$ & 34 & 66.6 \\
\hline $15-$ & 3 & 61.6 \\
\hline $16-$ & 71 & \multirow{10}{*}{1154.6} \\
\hline $17-$ & 34 & \\
\hline $18-$ & 56 & \\
\hline $19-$ & 54 & \\
\hline $20-$ & 69 & \\
\hline $21-$ & 28 & \\
\hline $22-$ & 30 & \\
\hline $23-$ & 47 & \\
\hline $24-$ & 35 & \\
\hline $25-$ & 32 & \\
\hline Average score & 985 & 72.16 \\
\hline
\end{tabular}




\section{APPENDIX 2}

Table 2. GPA after first semester for both groups

\begin{tabular}{|c|c|c|}
\hline Student \# & Group A GPA & Group B GPA \\
\hline $1-$ & 4.13 & 2.92 \\
\hline $2-$ & 4.77 & 4.20 \\
\hline $3-$ & 1.75 & 3.02 \\
\hline 4- & 3.88 & 4.40 \\
\hline $5-$ & 0.00 & 4.21 \\
\hline 6- & 4.59 & 3.51 \\
\hline $7-$ & 3.52 & 2.80 \\
\hline $8-$ & 3.41 & 4.28 \\
\hline 9- & 3.41 & 4.07 \\
\hline $10-$ & 1.65 & 4.56 \\
\hline $11-$ & 4.66 & 3.30 \\
\hline $12-$ & 3.78 & 2.47 \\
\hline $13-$ & 2.84 & 2.70 \\
\hline $14-$ & 3.42 & 2.60 \\
\hline $15-$ & 4.00 & 2.60 \\
\hline $16-$ & 4.78 & 4.18 \\
\hline $17-$ & 4.03 & 3.88 \\
\hline $18-$ & 4.16 & 2.92 \\
\hline $19-$ & 4.89 & 4.02 \\
\hline 20 & 3.78 & 2.96 \\
\hline $21-$ & 4.30 & 4.46 \\
\hline $22-$ & 1.69 & \\
\hline $23-$ & 3.83 & \\
\hline $24-$ & 3.97 & \\
\hline $25-$ & 3.88 & \\
\hline Average score & 3.56 & 3.52 \\
\hline
\end{tabular}

Only 25 students participated in the placement test from group A, hile all students in group B have participated. 


\section{APPENDIX 3}

Table 3. Average GPA for the total number of students in Group A

\begin{tabular}{|c|c|c|c|}
\hline Student \# & Group A GPA & Student \# (continue) & Group A GPA (continue) \\
\hline $1-$ & 4.13 & $31-$ & 3.99 \\
\hline $2-$ & 4.77 & $32-$ & 3.90 \\
\hline $3-$ & 1.75 & $33-$ & 3.73 \\
\hline 4- & 3.88 & $34-$ & 3.70 \\
\hline $5-$ & 0.00 & $35-$ & 3.58 \\
\hline $6-$ & 4.59 & $36-$ & 3.45 \\
\hline $7-$ & 3.52 & $37-$ & 3.41 \\
\hline $8-$ & 3.41 & $38-$ & 3.40 \\
\hline $9-$ & 3.41 & $39-$ & 3.33 \\
\hline $10-$ & 1.65 & $40-$ & 3.15 \\
\hline $11-$ & 4.66 & $41-$ & 2.73 \\
\hline $12-$ & 3.78 & $42-$ & 2.71 \\
\hline $13-$ & 2.84 & 43- & 2.70 \\
\hline $14-$ & 3.42 & $44-$ & 2.58 \\
\hline $15-$ & 4.00 & $45-$ & 2.54 \\
\hline $16-$ & 4.78 & $46-$ & 2.47 \\
\hline $17-$ & 4.03 & $47-$ & 2.21 \\
\hline $18-$ & 4.16 & $48-$ & 2.08 \\
\hline 19- & 4.89 & 49- & 4.00 \\
\hline 20 & 3.78 & $50-$ & 2.6 \\
\hline $21-$ & 4.30 & $51-$ & 2.22 \\
\hline $22-$ & 1.69 & $52-$ & 1.78 \\
\hline $23-$ & 3.83 & 53- & 1.00 \\
\hline $24-$ & 3.97 & $54-$ & 1.00 \\
\hline $25-$ & 3.88 & $55-$ & 1.00 \\
\hline $26-$ & 4.38 & 56- & 1.00 \\
\hline $27-$ & 4.34 & $57-$ & 000 \\
\hline $28-$ & 4.31 & $58-$ & 000 \\
\hline $29-$ & 4.14 & $59-$ & 000 \\
\hline $30-$ & 4.08 & $60-$ & \\
\hline \multicolumn{2}{|l|}{ Average GPA } & & 3.06 \\
\hline
\end{tabular}

\section{APPENDIX 4}

Table 4. Average GPA score for the total number of students studying in level 1 in group B Number of students Average GPA score 21 3.52

\section{APPENDIX 5}

Table 5. Grade codes and average points as stated in the Higher Education Handbook

\begin{tabular}{c|c}
\hline Grade Codes & Credit / points \\
\hline $\mathrm{A}+$ & 5.0 \\
\hline $\mathrm{A}$ & 4.75 \\
\hline $\mathrm{B}+$ & 4.5 \\
\hline $\mathrm{B}$ & 4.0 \\
\hline $\mathrm{C}+$ & 3.5 \\
\hline $\mathrm{C}$ & 3.0 \\
\hline $\mathrm{D}+$ & 2.5 \\
\hline $\mathrm{D}$ & 2.0 \\
\hline $\mathrm{F}$ & 1.0 \\
\hline
\end{tabular}




\section{APPENDIX 6}

Table 6. students grades in English subject at high school VS grades in the placement test

\begin{tabular}{|c|c|c|}
\hline Student \# & $\begin{array}{c}\text { Group A } \\
\text { Test R. }\end{array}$ & $\begin{array}{c}\text { English subject grades in third year } \\
\text { of High school }\end{array}$ \\
\hline $1-$ & 24 & 84 \\
\hline $2-$ & 62 & 99 \\
\hline $3-$ & 28 & 81 \\
\hline 4- & 36 & 85 \\
\hline $5-$ & 25 & 85 \\
\hline $6-$ & 52 & 85 \\
\hline $7-$ & 33 & 99 \\
\hline $8-$ & 28 & 91 \\
\hline $9-$ & 33 & 79 \\
\hline $10-$ & 23 & 70 \\
\hline $11-$ & 67 & 98 \\
\hline $12-$ & 36 & 87 \\
\hline $13-$ & 45 & 77 \\
\hline $14-$ & 34 & 91 \\
\hline $15-$ & 3 & 73 \\
\hline $16-$ & 71 & 100 \\
\hline $17-$ & 34 & 97 \\
\hline $18-$ & 56 & 85 \\
\hline 19- & 54 & 85 \\
\hline $20-$ & 69 & 75 \\
\hline $21-$ & 28 & 87 \\
\hline $22-$ & 30 & 87 \\
\hline $23-$ & 47 & 89 \\
\hline $24-$ & 35 & 70 \\
\hline $25-$ & 32 & 82 \\
\hline Average score & 985 & \\
\hline
\end{tabular}


NOTES 